\title{
Selective Cytotoxic Effect of ZnO Nanoparticles on Glioma Cells
}

\author{
Stella Ostrovsky ${ }^{1}$, Gila Kazimirsky ${ }^{2}$, Aharon Gedanken $^{1}(\varangle)$, and Chaya Brodie ${ }^{2}$ \\ ${ }^{1}$ Department of Chemistry and Kanbar Laboratory for Nanomaterials at the Bar-Ilan University Center for Advanced Materials and \\ Nanotechnology, Bar-Ilan University, Ramat-Gan 52900, Israel \\ ${ }^{2}$ The Mina and Everard Goodman Faculty of Life Sciences, Bar-Ilan University, Ramat-Gan 52900, Israel \\ Received: 7 May 2009 / Revised: 6 August 2009 / Accepted: 18 September 2009 \\ (C) Tsinghua University Press and Springer-Verlag 2009. This article is published with open access at Springerlink.com
}

\begin{abstract}
In this study we examined the cytotoxic effect of $\mathrm{ZnO}$ nanoparticles on various human cancer and normal cells. We found that the $\mathrm{ZnO}$ nanoparticles exerted a cytotoxic effect on the human glioma cell lines A172, U87, LNZ308, LN18, and LN229, whereas no cytotoxic effect was observed on normal human astrocytes. Similarly, the $\mathrm{ZnO}$ nanoparticles induced cell death in breast and prostate cancer cell lines while no major effect was observed in the respective normal breast and prostate cell lines. Using the fluorescent dye 2,7-dichlorofluorescein diacetate, we found that treatment of the glioma cells with $\mathrm{ZnO}$ nanoparticles induced a large increase in the generation of reactive oxygen species (ROS) and treatment of the cells with $\mathrm{N}$-acetyl cysteine decreased the cytotoxic effect of the $\mathrm{ZnO}$ nanoparticles. In contrast, a smaller effect on ROS generation was observed in the normal astrocytes. These results suggest that $\mathrm{ZnO}$ nanoparticles may be employed as a selective cytotoxic agent for the eradication of cancer cells.
\end{abstract}

\section{KEYWORDS}

ZnO nanoparticles, sonochemistry, cancer cells

\section{Introduction}

Nanoparticles are making significant contributions to the development of new approaches of drug delivery in cancer and can provide a platform for combined therapeutics with subsequent monitoring of response $[1,2]$. Progress in utilizing inorganic nanoparticles for biomedical applications has advanced rapidly due to the extensive amount of work done in the synthesis and modification of these particles [1]. Among inorganic materials, metal oxide nanoparticles are of special interest. Zinc oxide $(\mathrm{ZnO})$ belongs to a group of metal oxides, which is characterized by photocatalytic ability, and photo-oxidizing capacity against chemical and biological species [2]. Moreover, $\mathrm{ZnO}$ utilizes a multifunctional nanoplatform that bombards malignant cells from the outside, through the external release of reactive oxygen species (ROS) [3]. However, the anti-cancer properties of zinc oxide $(\mathrm{ZnO})$ nanoparticles remain an undeveloped area which is of potential medical interest. In the present study we investigated the cytotoxic effect of these nanoparticles against glioma and other tumor cells.

Gliomas are the most frequent primary brain tumors, accounting for $>50 \%$ of all brain tumors [4]. Glioblastomas, the most malignant form, are

Address correspondence to gedanken@mail.biu.ac.il 
characterized by increased proliferation and invasion into the surrounding normal brain tissue [5]. Current treatment options include surgery, radiation therapy, and chemotherapy. However, these tumors are resistant to the different forms of chemotherapy and radiotherapy, which impacts patient survival. Indeed, the prognosis of patients with glioblastomas remains extremely poor, and the median survival of 12 months from the time of diagnosis has not significantly changed during the last few years [6]. Therefore, the search for novel and more effective chemotherapeutic agents against glioma cells is of utmost importance.

In this study we generated $\mathrm{ZnO}$ nanoparticles via ultrasound irradiation, which has been described as an effective technique for the synthesis of nanophase materials [7]. The effect of $\mathrm{ZnO}(60 \mathrm{~nm})$ nanoparticles was examined on the human glioma cell lines U87, A172, U251, LNZ308, LN18, LN229, and on human normal astrocytes as well as on breast and prostate cancer cells and their respective normal cell lines.

\section{Results and discussion}

\subsection{Particle characterization}

The zinc oxide nanoparticles were formed using sonchemical irradiation according to the following reactions:

1) $\mathrm{Zn}(\mathrm{OAc})_{2(\mathrm{~s})} \longrightarrow \mathrm{Zn}^{2+}{ }_{\text {aq })}+2 \mathrm{OAc}^{-}{ }_{(\mathrm{aq})}$

2) $\mathrm{Zn}^{2+}{ }_{(\mathrm{aq})}+2 \mathrm{OH}^{-}{ }_{(\mathrm{aq})} \longrightarrow \mathrm{Zn}(\mathrm{OH})_{2(\mathrm{~s})}$ $\longrightarrow \mathrm{ZnO}_{(\mathrm{s})}+\mathrm{H}_{2} \mathrm{O}$

The sonochemical irradiation of a liquid causes two primary effects, namely, cavitation (bubble formation, growth, and collapse), and heating. When the microscopic cavitation bubbles collapse near the surface of the substrate, they generate powerful shock waves and microjets that cause effective stirring/mixing of the disturbed layer of liquid. The after effects of the cavitation are several hundred times greater in heterogeneous systems than in homogeneous systems [8]. In our case, the ultrasonic waves promote the fast production of the newly-formed zinc oxide $(\mathrm{ZnO})$ nanoparticles.

The X-ray diffraction (XRD) patterns (Fig. 1) of sonochemically-synthesized $\mathrm{ZnO}$ nanoparticles demonstrate that the zinc oxide is crystalline in nature, and the diffraction peaks match very well a hexagonal phase of $\mathrm{ZnO}$ (PDF: 89-7102). The peaks at $2 \theta=31.77^{\circ}$, $34.42^{\circ}, 36.25^{\circ}, 47.54^{\circ}, 56.6^{\circ}, 62.85^{\circ}$, and $67.95^{\circ}$ are assigned to the (100), (002), (101), (102), (110), (103), and (112) reflection lines of hexagonal $\mathrm{ZnO}$ particles, respectively. No characteristic peaks of any impurities were detected. The particle size estimated by the Debye-Scherrer (DS) equation is $60 \mathrm{~nm}$.

The shape and size of the above-mentioned product was determined by transmission electron microscopy (TEM) measurements as shown in Fig. 2. The TEM images of the as-prepared nanoparticles show isolated particles with an average diameter of $60 \mathrm{~nm} \pm 1 \mathrm{~nm}$ for the $\mathrm{ZnO}$, as well as a network of connected particles.

\subsection{ZnO nanoparticles exert a dose-dependent cytotoxic effect on glioma cells}

To examine the cytotoxic effect of the $\mathrm{ZnO}$ nanoparticles we first employed the A172, U87, and LNZ308 glioma cell lines and normal human astrocytes. The cells were treated with different concentrations of the $\mathrm{ZnO}$ nanoparticles (1.5

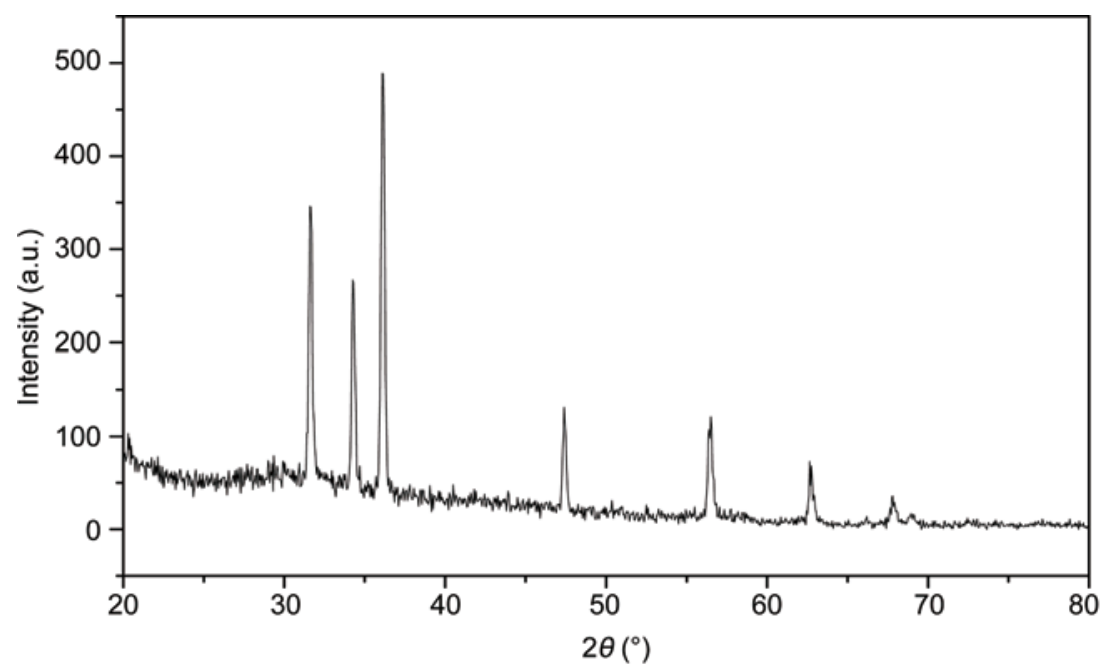

Figure 1 X-ray diffraction pattern of as-prepared $\mathrm{ZnO}$ nanoparticles. The XRD patterns demonstrate the crystalline nature of zinc oxide. The peaks in order of increasing $2 \theta$ are assigned to the (100), (002), (101), (102), (110), (103), and (112) reflection lines of hexagonal $\mathrm{ZnO}$ particles. No characteristic peaks of any impurities were detected. The particle size estimated by the Debye-Scherrer (DS) equation is $60 \mathrm{~nm}$ 


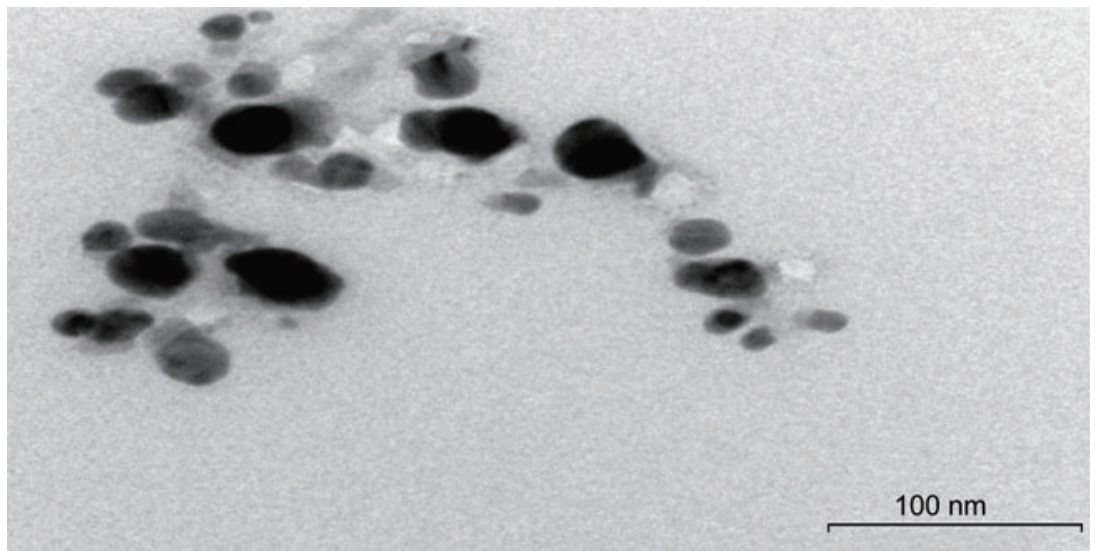

Figure 2 Transmission electron micrograph of the as-prepared zinc oxide nanoparticles, showing isolated particles with an average diameter of $60 \mathrm{~nm} \pm 1 \mathrm{~nm}$, as well as a network of connected particles

and $10 \mathrm{mmol} / \mathrm{L}$ ) and the cytotoxic effect of the nanoparticles was determined using the measurement of lactate dehydrogenase $(\mathrm{LDH})$ release into the culture supernatant. As presented in Fig. 3(a), some cytotoxic effect was already observed at 1 and $5 \mathrm{mmol} / \mathrm{L} \mathrm{ZnO}$ nanoparticles whereas maximal effect was obtained at a concentration of $10 \mathrm{mmol} / \mathrm{L}$ nanoparticles. Similar effects were obtained in the two additional glioma cell lines, LN18 and LN229, treated with $10 \mathrm{mmol} / \mathrm{L} \mathrm{ZnO}$ nanoparticles (Fig. 3(b)). In contrast, no significant cytotoxic effect was observed in the normal human astrocytes at the highest concentration $(10 \mathrm{mmol} / \mathrm{L})$ of the nanoparticles that significantly effected the cancer cells (Fig. 3(c)), suggesting that the effect of the $\mathrm{ZnO}$ nanoparticles was selective for the glioma cell lines.

\subsection{Selective cytotoxic effect of $\mathrm{ZnO}$} nanoparticles on breast and prostate cancer cells

We further examined the selective cytotoxic effect of the $\mathrm{ZnO}$ nanoparticles in breast and prostate cancer cells. In these studies we employed the breast cancer cell line MCF-7 cancer cells and the normal breast cell line MCF-10A. Both cell lines were treated with 10 $\mathrm{mmol} / \mathrm{L} \mathrm{ZnO}$ nanoparticles and LDH assay was performed $24 \mathrm{~h}$ thereafter. As shown in Fig. 4(a), the $\mathrm{ZnO}$ nanoparticles induced cell death only in the MCF-7 cancer cells, whereas no significant changes were observed in the viability of the MCF10 A normal cells. Similar results were obtained with the prostate cells. Thus, treatment of the prostate cancer cell line PC-3 with $10 \mathrm{mmol} / \mathrm{L} \mathrm{ZnO}$ nanoparticles induced a large cytotoxic effect in these cells (Fig. 4(b)), whereas no cell death was observed in the normal RWPE-1 prostate cells.

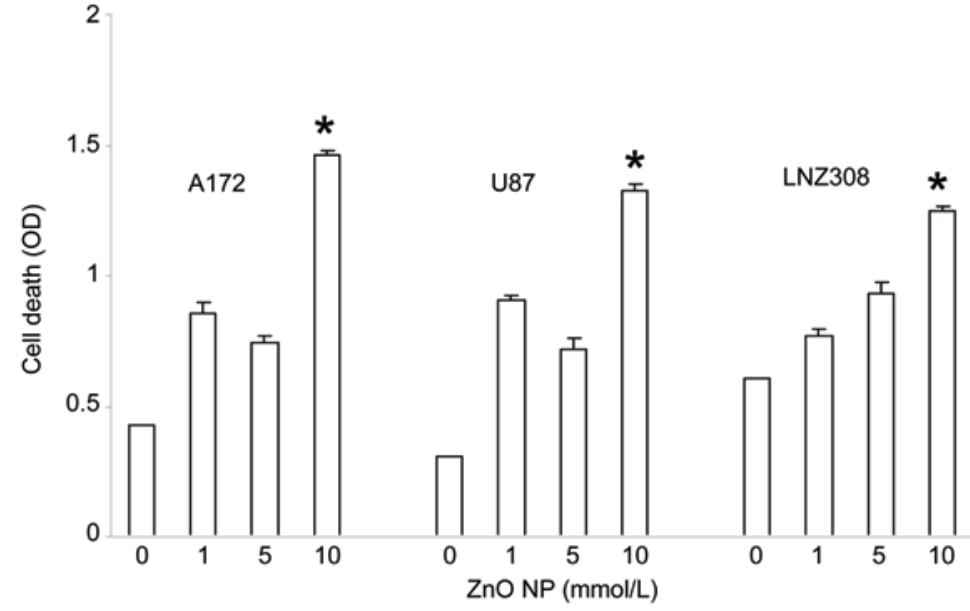

(a)

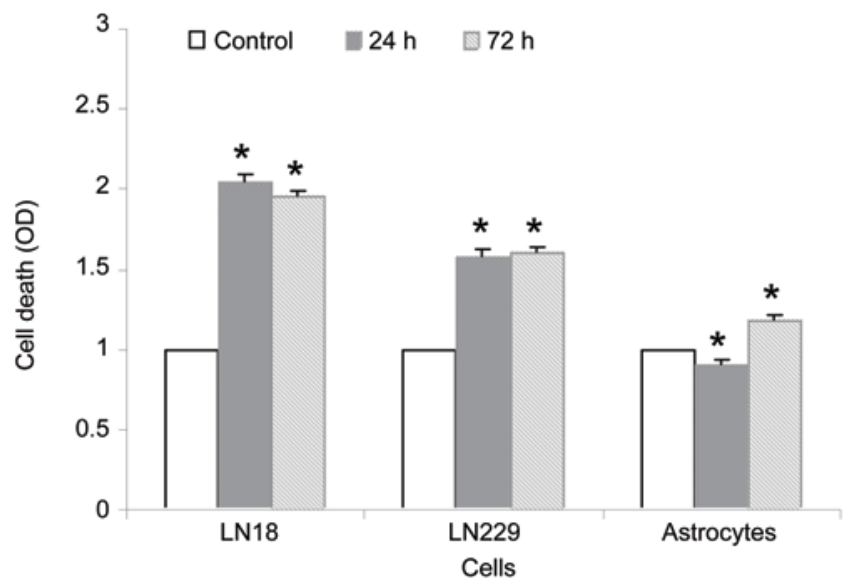

(b)

Figure 3 Cytotoxic effect of $\mathrm{ZnO}$ nanoparticles in glioma cell lines. The glioma cell lines A172, U87, and LNZ308 were treated with different concentrations of ZnO nanoparticles ( $1 \mathrm{mmol} / \mathrm{L}, 5 \mathrm{mmol} / \mathrm{L}$, and $10 \mathrm{mmol} / \mathrm{L}$ ) for $24 \mathrm{~h} \mathrm{(a).} \mathrm{The} \mathrm{glioma}$ cell lines LN18, LN229, and normal human astrocytes (b) were treated with 10 $\mathrm{mmol} / \mathrm{L}$ nanoparticles for $24 \mathrm{~h}$ and $72 \mathrm{~h}$. The cytotoxicity of the nanoparticles was determined using LDH analysis in the culture supernatants and is expressed in terms of the optical density (OD) at $490 \mathrm{~nm}$. The results are the means \pm SD from three independent experiments ${ }^{*} p<0.0001$ 


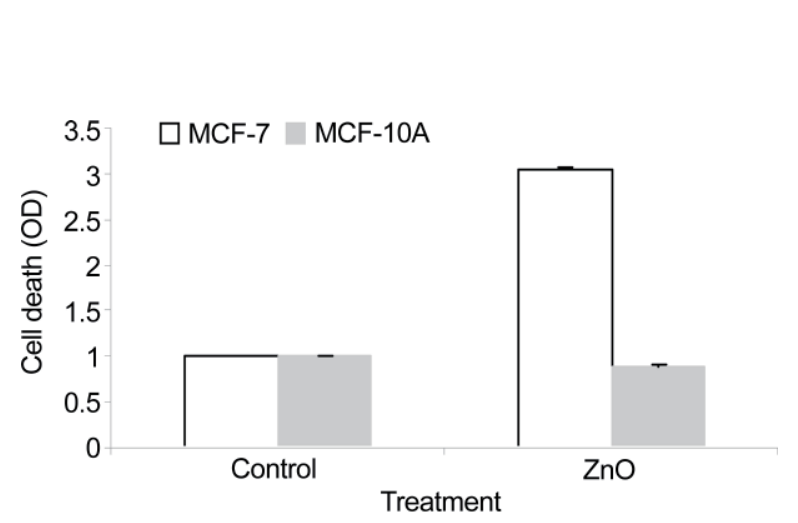

(a)

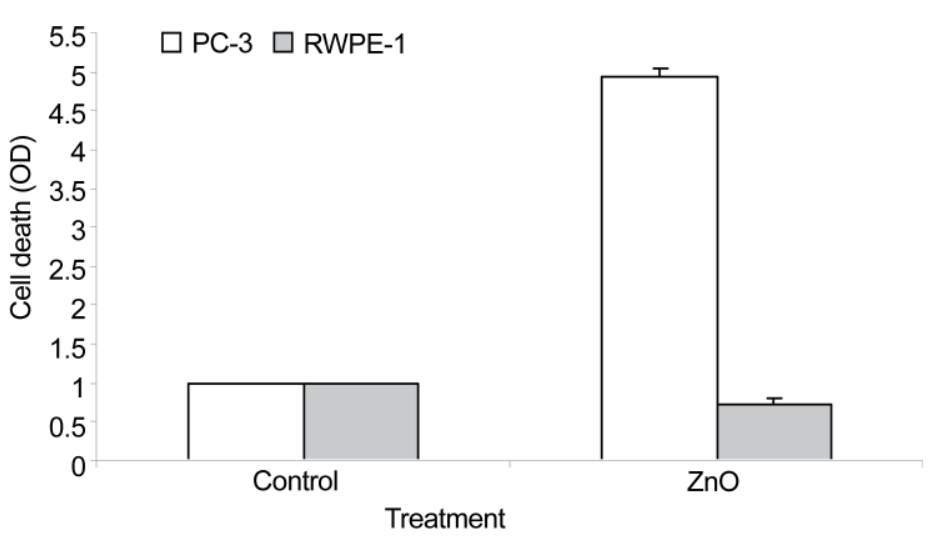

(b)

Figure 4 Cytotoxic effect of $\mathrm{ZnO}$ nanoparticles in breast cancer and normal cells, and prostate cancer and normal cells. The breast cancer cells MCF-7 (a), the normal breast cells MCF10A, the prostate cancer cells PC-3 (b) and the normal prostate cells, RWPE-1 were treated with $10 \mathrm{mmol} / \mathrm{L} \mathrm{ZnO}$ nanoparticles for $24 \mathrm{~h}$. The cytotoxicity of the nanoparticles was determined using LDH analysis in the culture supernatants and expressed in terms of the optical density (OD) at $490 \mathrm{~nm}$. The results are the means \pm SD from three independent experiments $* p<0.0001$

\subsection{ZnO nanoparticles induce cell apoptosis in glioma cells}

To investigate whether the cytotoxic effect of the $\mathrm{ZnO}$ nanoparticles is associated with the induction of cell apoptosis we treated the U87 and LNZ308 glioma cells with 1, 5, and $10 \mathrm{mmol} / \mathrm{L} \mathrm{ZnO}$ nanoparticles for 24 and $72 \mathrm{~h}$ and analyzed cell apoptosis by propidium iodide staining and fluorescence-activated cell sorting (FACS) analysis. $\mathrm{ZnO}$ nanoparticles induced only a minor increase in cell apoptosis after $24 \mathrm{~h}$ of treatment (data not shown), whereas significant cell apoptosis was observed after $72 \mathrm{~h}$ of treatment in all the cell lines that were examined (Fig. 5(a)). In contrast, and similar to the results of the $\mathrm{LDH}$ analysis, no significant cell apoptosis was observed in the normal human astrocytes after treatment for either 24 or $72 \mathrm{~h}$ with $10 \mathrm{mmol} / \mathrm{L} \mathrm{ZnO}$ nanoparticles (Fig. 5(b)).

\subsection{ZnO nanoparticles induce generation of ROS in glioma cells}

To delineate the mechanisms involved in the cytotoxic effect of the $\mathrm{ZnO}$ nanoparticles we examined the effect

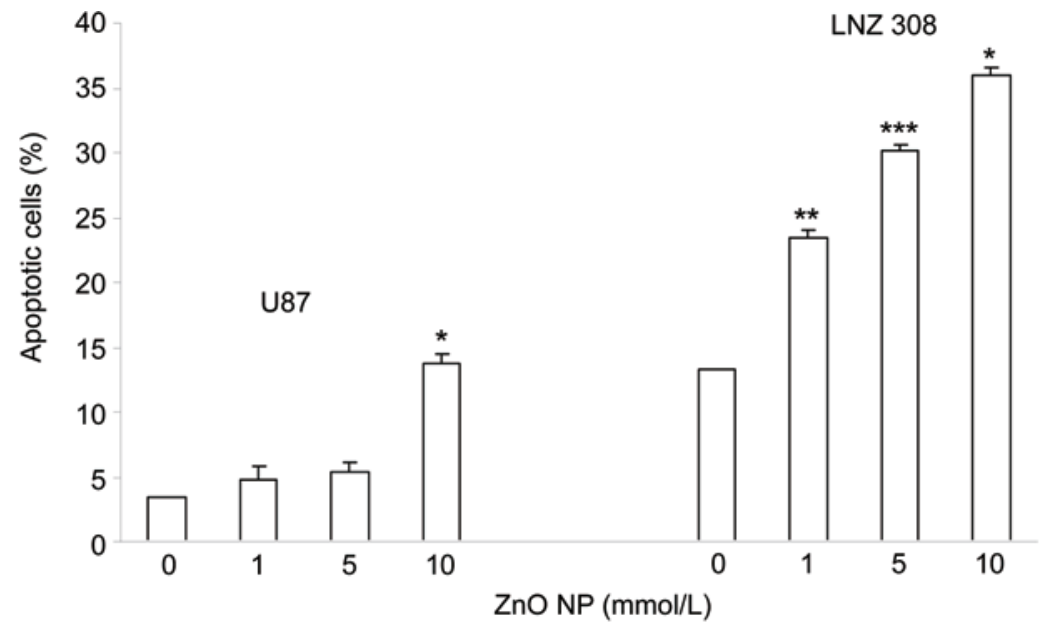

(a)

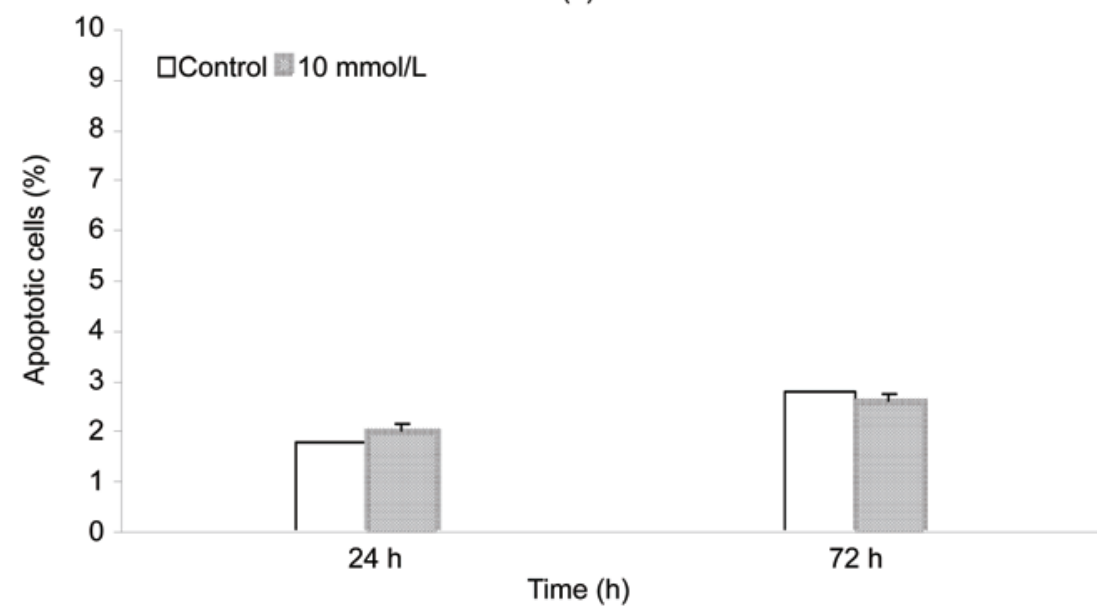

(b)

Figure 5 ZnO nanoparticles induce cell apoptosis in glioma cells. The U87 and LNZ308 glioma cells (a) were treated with $1 \mathrm{mmol} / \mathrm{L}, 5 \mathrm{mmol} / \mathrm{L}$, and $10 \mathrm{mmol} / \mathrm{L} \mathrm{ZnO}$ nanoparticles for $72 \mathrm{~h}$ and normal human astrocytes (b) were treated with $10 \mathrm{mmol} / \mathrm{L} \mathrm{ZnO}$ nanoparticles for $24 \mathrm{~h}$ and $72 \mathrm{~h}$. Cell apoptosis was determined using propidium iodide staining and FACS analysis. The results are the means \pm SD from three independent experiments ${ }^{*} p<0.005$, ${ }^{* *} p<0.05,{ }^{* * *} p<0.01$ 
of these nanoparticles on the generation of ROS in the glioma cells and normal human astrocytes. U87 cells or normal astrocytes were treated with $10 \mathrm{mmmol} / \mathrm{L}$ $\mathrm{ZnO}$ nanoparticles for $24 \mathrm{~h}$ and the generation of ROS was examined using 2,7-dichlorofluorescein diacetate (DCFH-DA), a specific fluorescent probe commonly used for the detection of intracellular ROS [9]. DCFH-DA is cell permeable, and, after uptake, it is cleaved by intracellular esterases to 2,7-dichlorofluorescin (DCFH), which is trapped within the cells, and is oxidized to the fluorescent molecule 2,7-dichlorofluorescein (DCF) by ROS. This highly fluorescent derivative is readily detectable using flow cytometry. We found an increase in the fluorescence intensity of DCF after $24 \mathrm{~h}$ exposure to $10 \mathrm{mmmol} / \mathrm{L} \mathrm{ZnO}$ nanoparticles in the U87 cells (Fig. 6(a)). As a positive control in these experiments we used hydrogen peroxide $\mathrm{H}_{2} \mathrm{O}_{2}$ [10]. In contrast, the $\mathrm{ZnO}$ nanoparticles induced a smaller increase in the fluorescence intensity of DCF in the normal astrocytes cells as compared to $\mathrm{H}_{2} \mathrm{O}_{2}$ (Fig. 6(b)).

\subsection{Role of ROS in the cytotoxic effect of the $\mathrm{ZnO}$ nanoparticles}

To determine the role of ROS in the cytotoxic effect of the $\mathrm{ZnO}$ nanoparticles, we employed the ROS

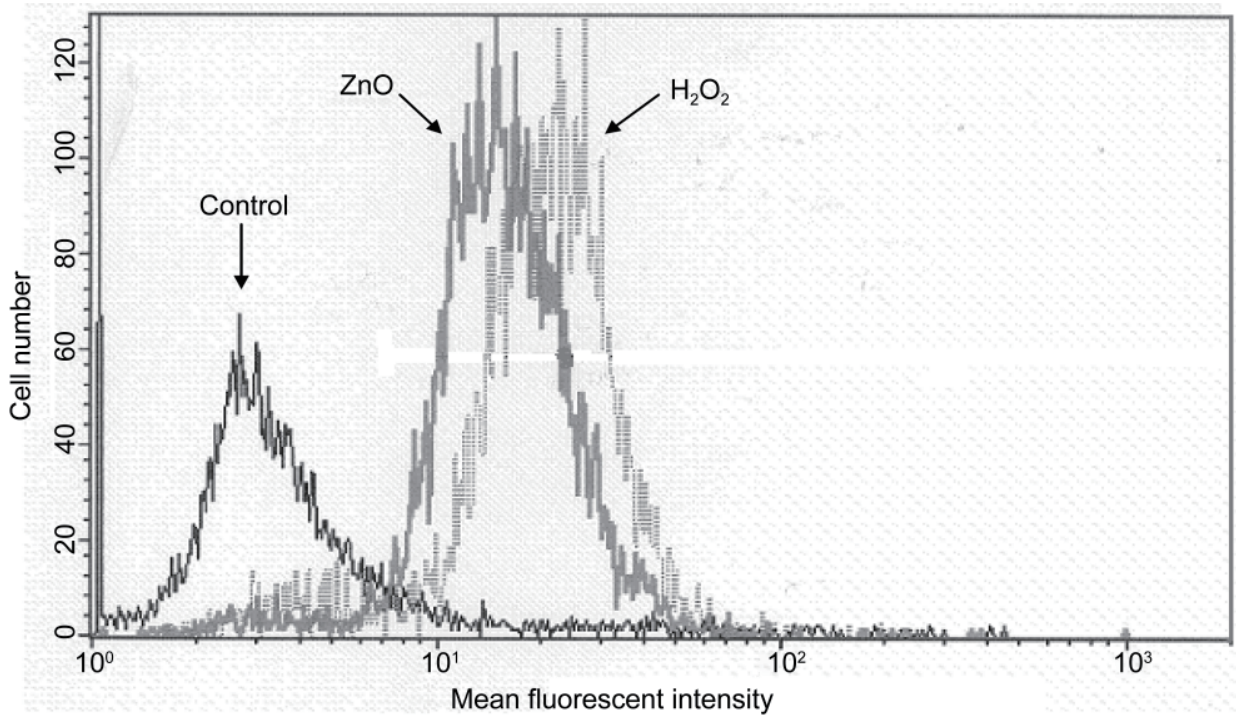

(a)

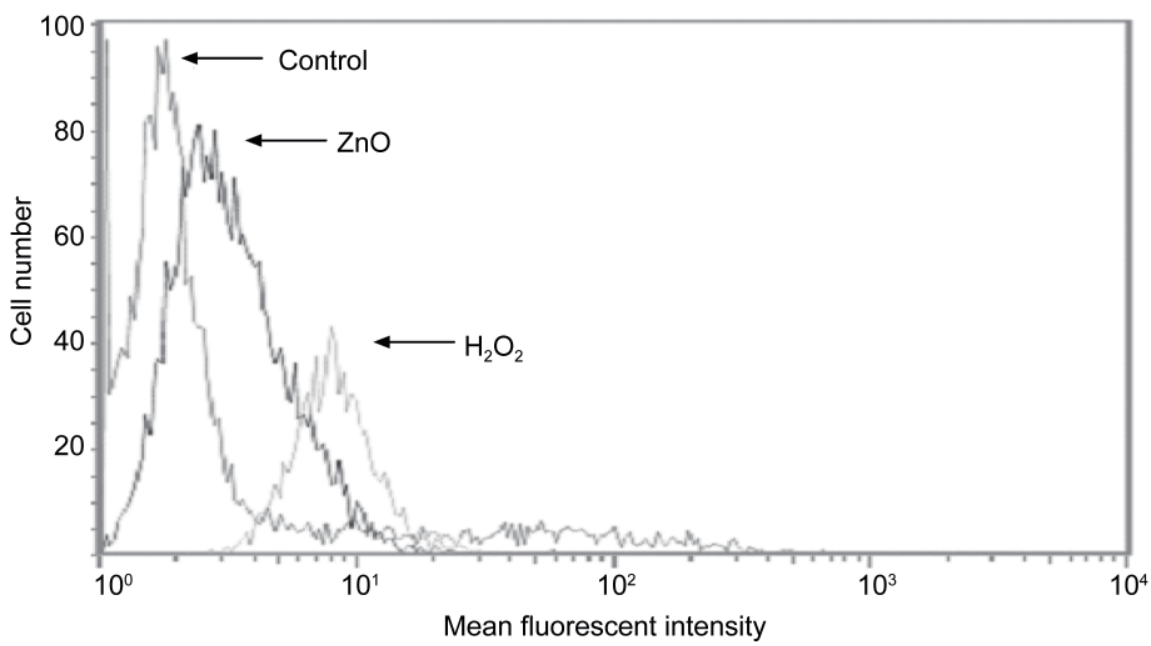

(b)

Figure 6 Generation of ROS in glioma and normal cells treated with $\mathrm{ZnO}$ nanoparticles. The generation of ROS was determined in U87 cells (a) or astrocytes (b) treated with $10 \mathrm{mmol} / \mathrm{L} \mathrm{ZnO}$ nanoparticles for $24 \mathrm{~h}$ using the oxidation sensitive dye DCFH-DA and FACS analysis. Representative histograms of ROS production in U87 glioma cells or astrocyte normal cells are compared to $\mathrm{H}_{2} \mathrm{O}_{2}$ as a positive control 
quencher, $N$-acetyl cysteine (NAC) [11]. U87 cells were treated with $10 \mathrm{mmol} / \mathrm{L} \mathrm{NAC}$ prior to their treatment with the $\mathrm{ZnO}$ nanoparticles and cell apoptosis was determined after $24 \mathrm{~h}$. As shown in Fig. 7, treatment of the U87 cells with $10 \mathrm{mmol} / \mathrm{L}$ $\mathrm{ZnO}$ for $24 \mathrm{~h}$ resulted in around $10 \%$ apoptotic cells. The effect of the $\mathrm{ZnO}$ nanoparticles was completely absent in cells pre-treated with NAC, suggesting that generation of $\mathrm{ROS}$ by the $\mathrm{ZnO}$ nanoparticles mediated their apoptotic effect.

Recent developments in cancer research suggest that a number of apoptotic stimuli share common mechanistic pathways characterized by the generation of ROS through oxidative stress [12]. ROS typically include the superoxide radical $\left(\mathrm{O}_{2}^{-}\right)$, hydrogen peroxide $\left(\mathrm{H}_{2} \mathrm{O}_{2}\right)$, and the hydroxyl radical $(\cdot \mathrm{OH})$ which cause damage to cellular components such as lipids, DNA, and proteins and eventually leads to cell death [13]. In agreement with previous reports, we found that the $\mathrm{ZnO}$ nanoparticles induced the generation of ROS in the glioma cells, whereas normal astrocytes exhibited lower levels of ROS in response to the $\mathrm{ZnO}$ nanoparticles. Moreover, our results using NAC demonstrated that the ROS contributed to the apoptotic effect of the $\mathrm{ZnO}$ nanoparticles.

Our results suggest that the basis for the selective effect of the $\mathrm{ZnO}$ nanoparticles on cancer cells may be due to the increased generation of ROS and to an increased sensitivity of these cells to oxidative stress. Indeed, it has been shown that leukemia and ovarian cancer cells are more sensitive to different agents that generate ROS such as 2-methoxyestradiol [14]. It is worth mentioning that the toxicity on the cancer cells is a result of the exposure to the $\mathrm{ZnO}$ nanoparticles alone, and not a result of photoexposure of the $\mathrm{ZnO}$ nanoparticles.

\section{Conclusion}

In this study, we investigated the cytotoxic effects of $60-\mathrm{nm} \mathrm{ZnO}$ nanoparticles, synthesized by the sonochemical technique, on normal and tumor cells focusing on glioma cells. The effect of the $\mathrm{ZnO}$ nanoparticles on cell death and apoptosis was characterized and the role of ROS in the cytotoxic effect of these nanoparticles was determined.

In contrast to their cytotoxic effect on the different glioma cells, the $\mathrm{ZnO}$ nanoparticles did not exert any cytotoxic effect, even at a concentration of $10 \mathrm{mmol} / \mathrm{L}$, on normal human astrocytes. Similarly, the $\mathrm{ZnO}$ nanoparticles induced cell death in breast and prostate cancer cells but did not affect the viability of normal breast and prostate cells. Collectively, these results demonstrate that the $\mathrm{ZnO}$ nanoparticles exert selective cytotoxic effect on cancer cells. The ROS generated in response to treatment with the $\mathrm{ZnO}$

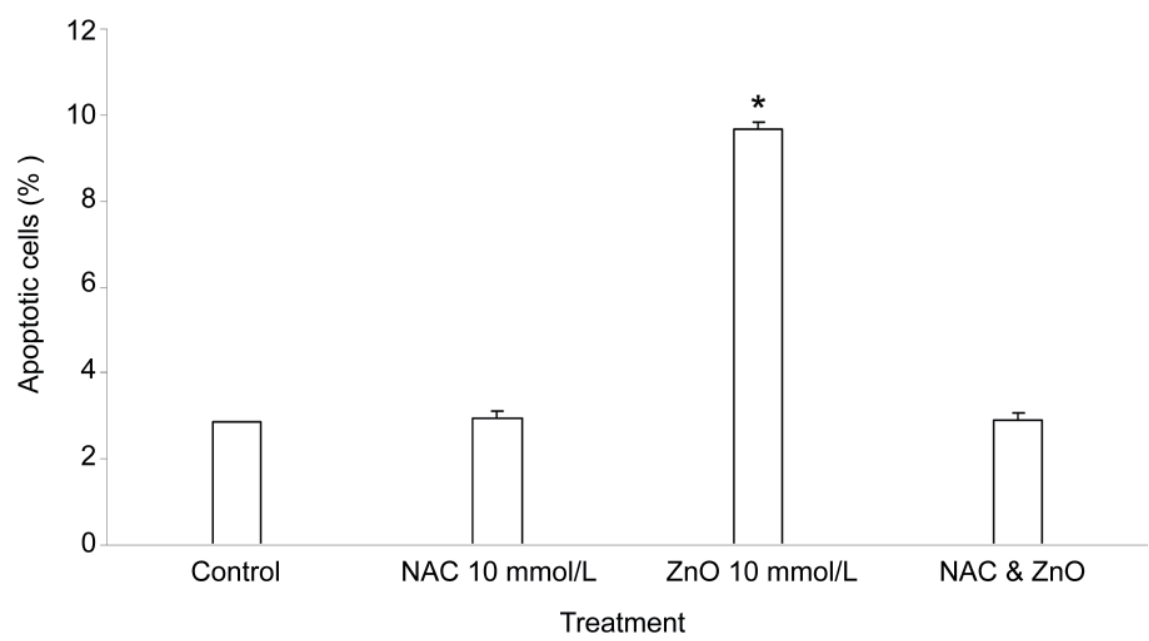

Figure 7 Quenching of ROS by $\mathrm{N}$-acetyl cysteine (NAC) protects U87 cells from ZnO nanoparticle-induced apoptosis. U87 cells were pre-treated with $10 \mathrm{mmol} / \mathrm{L}$ NAC prior to treatment with $10 \mathrm{mmol} / \mathrm{L} \mathrm{ZnO}$ nanoparticles for an additional $24 \mathrm{~h}$. Cell apoptosis was determined using propidium iodide staining and FACS analysis. The results show significant differences in cell death (\%) between treated and non-treated cells ${ }^{*} p<0.0001$ 
nanoparticles in the cancer cells is larger compared to that generated in the normal cells and together with the increased sensitivity of the cancer cells, result in selective cell death of these cells. The results of this study suggest that $\mathrm{ZnO}$ nanoparticles should be further exploited as a potential selective anti-cancer agent.

\section{Methods}

\subsection{Nanoparticles}

The synthesis of zinc oxide nanoparticles $(\mathrm{ZnO})$ with particle size of $60 \mathrm{~nm}$ was carried out as previously described [15]. Briefly, $2.5 \mathrm{~g}$ of zinc (II) acetate dihydrate (Aldrich 98+\%) was dissolved in $100 \mathrm{~mL}$ of $10 \%(v / v)$ water- $N, N$-dimethylformamide (DMF; Aldrich $99.8 \%$ ) and irradiated with a high intensity ultrasonic horn (Ti-horn, $20 \mathrm{kHz}, 100 \mathrm{~W} / \mathrm{cm}^{2}$ ) under a flow of argon at room temperature for $3 \mathrm{~h}$. The product obtained was washed thoroughly with doubly distilled water and finally with absolute ethanol and dried in vacuum.

Zinc oxide was first dispersed in phosphate buffered saline (PBS), then sonicated in a sonication bath to avoid aggregates, and used at final concentrations of $1,3,5,8$, and $10 \mathrm{mmol} / \mathrm{L}$ in culture media for 24 and $48 \mathrm{~h}$. Control wells contained cells with supplemented media $(2 \mathrm{~mL})$ without nanoparticles.

The XRD measurements were carried out with a Bruker D8 diffractometer. To prepare an XRD sample, an ethanol suspension containing the metal oxide particles was deposited drop-wise on a single crystal silicon substrate and dried to obtain a thin layer of the particles. The transmission electron micrographs (TEM) were obtained by employing a JEOL-JEM 100SX microscope. Samples for the TEM examination were prepared by suspending dried samples in absolute ethanol. A drop of the sample suspension was allowed to dry on a copper grid (400 mesh, Electron Microscopy Sciences) coated with a carbon film. Since the particles are heavily aggregated, the small separated particles detected in the TEM serve as our measure of the particle sizes.

\subsection{Cell lines}

The glioma cell lines A172, U87, LN18, and LN229 were obtained from American Type Culture Collection (Manassas, VA), and the LNZ308 cells were obtained from Oliver Bogler (M. D. Anderson Cancer Center). Cells were grown on tissue culture dishes at a concentration of $2 \times 10^{5}$ cells $/ \mathrm{mL}$ in Dulbecco's modified Eagle medium DMEM (Sigma) containing $10 \%$ heat-inactivated fetal calf serum (FCS), $2 \mathrm{mmol} / \mathrm{L}$ glutamine, penicillin ( 50 units $/ \mathrm{mL}$ ), and streptomycin $(0.05 \mathrm{mg} / \mathrm{mL})$. The medium was changed every 3 to 4 days and cultures were split using $0.25 \%$ trypsin. Normal astrocytes were obtained from Cambrex (Walkersville, MD). Cells were grown in an astrocytespecific medium provided by Cambrex. Equal numbers of cells $\left(2 \times 10^{5}\right.$ cells $\left./ \mathrm{mL}\right)$ were plated for all the experiments.

Breast cancer cells, MCF-7, breast normal cells MCF-10A [16], and prostate normal cells RWPE-1 were obtained from ATCC. The MCF-10A cells were grown in mammary epithelial basal medium (MEBM) supplied with bovine pituitary extract (BPE) $13 \mathrm{mg} / \mathrm{mL}, 2 \mathrm{~mL}$; hydrocortisone $0.5 \mathrm{mg} / \mathrm{mL}$, $0.5 \mathrm{~mL}$; human epidermal growth factor (hEGF) $10 \mu \mathrm{g} / \mathrm{mL}, 0.5 \mathrm{~mL}$; insulin $5 \mathrm{mg} / \mathrm{mL}, 0.5 \mathrm{~mL}$ ), at $37.0{ }^{\circ} \mathrm{C}$. The MCF-7 human breast tumor cells were maintained in Eagle's minimal essential medium (EMEM) containing $0.01 \mathrm{mg} / \mathrm{mL}$ bovine insulin; fetal bovine serum to a final concentration of $10 \%$, in air $95 \%$ / carbon dioxide $\left(\mathrm{CO}_{2}\right) 5 \%$, at $37.0^{\circ} \mathrm{C}$.

The RWPE-1 normal cells [17] were grown in a base medium, keratinocyte serum-free medium (K-SFM), provided by Gibco. To make the complete growth medium, we added the following components to the base medium: $0.05 \mathrm{mg} / \mathrm{mL}$ BPE, $5 \mu \mathrm{g} / \mathrm{mL}$ EGF in air $95 \%$ / carbon dioxide $\left(\mathrm{CO}_{2}\right) 5 \%$ at $37.0^{\circ} \mathrm{C}$.

\subsection{Measurements of cell apoptosis}

Cell apoptosis [18] was measured using propidium iodide staining and analysis by flow cytometry [19]. The cells were scraped and centrifuged with the supernatant medium at $3500 \mathrm{rpm}$ for $5 \mathrm{~min}$. Following washes, cells were resuspended in PBS and fixed in $70 \%$ ethanol for $1 \mathrm{~h}$ on ice. Fixed cells were washed with PBS and stained with propidium 
iodide $(5 \mu \mathrm{g} / \mathrm{mL})$ solution containing ribonuclease (RNase) $(50 \mu \mathrm{mol} / \mathrm{L})$. Cells were then analyzed on a Becton-Dickinson FACSCalibur flow cytometer. The sub- $\mathrm{G}_{0}$ population of the cells was determined.

\subsection{LDH measurement}

LDH levels were determined in the culture supernatants using a commercial LDH Kit (Pointe Scientific, Inc., Lincoln Park, MI, USA). This is a colorimetric assay that quantitatively measures $\mathrm{LDH}$, a stable cytosolic enzyme that is released upon cell lysis. Released LDH in culture supernatants was measured with a 30-min coupled enzymatic assay that results in the conversion of a tetrazolium salt (INT) into a red formazan product. The amount of color formed is proportional to the number of lysed cells [20]. $100 \mu \mathrm{L}$ of cell medium was used for LDH analysis. Absorbance at $490 \mathrm{~nm}$ was measured with a standard microplate reader (Victor3 multilabel counter, PerkinElmer, Boston, MA). Each experiment was done in triplicate.

\subsection{Intracellular ROS measurement}

The production of intracellular ROS was measured using DCFH-DA [21]. DCFH-DA passively enters the cell where it reacts with ROS to form the highly fluorescent compound DCF. Briefly, $10 \mathrm{mmol} / \mathrm{L}$ DCFH-DA stock solution (in methanol) was diluted 500-fold in DMEM medium without phenol red to yield a $20 \mu \mathrm{mol} / \mathrm{L}$ working solution. After $24 \mathrm{~h}$ of exposure to $\mathrm{ZnO}$ nanoparticles, the cells in the 6-well plate were washed twice with the medium and then incubated in $2 \mathrm{~mL}$ working solution of DCFH-DA at $37^{\circ} \mathrm{C}$ for $30 \mathrm{~min}$. Fluorescence was then determined at 485-nm excitation and 520-nm emission using a microplate reader.

\subsection{ROS quenching}

To determine the role of $\mathrm{ROS}$ in $\mathrm{ZnO}$ nanoparticleinduced cell death, U87 cells were seeded in a 12-well plate at $1 \mathrm{~mL}$ per well at a concentration of $2 \times 10^{5}$ cells $/ \mathrm{mL}$. A stock solution of $N$-acetyl cysteine (NAC, Sigma Aldrich) was prepared in PBS and added to cells at $10 \mathrm{mmol} / \mathrm{L}$ for $1 \mathrm{~h}$. After NAC pretreatment, cells were cultured with $10 \mathrm{mmol} / \mathrm{L}$ $\mathrm{ZnO}$ nanoparticles for $24 \mathrm{~h}$.

\section{References}

[1] Liong, M.; Lu, J.; Kovochich, M.; Xia, T.; Ruehm, S. G.; Nel, A. E.; Tamanoi, F.; Zink, J. I. Multifunctional inorganic nanoparticles for imaging, targeting, and drug delivery. ACS Nano 2008, 2, 889-896.

[2] Szabo, T.; Nemeth, J.; Dekany, I. Zinc oxide nanoparticles incorporated in ultrathin layer silicate films and their photocatalytic properties. Coll. Surf. A 2003, 230, 2335.

[3] Yamamoto, O.; Hotta, M.; Sawai, J.; Sasamoto, T.; Kojima, $\mathrm{H}$. Influence of powder characteristic of $\mathrm{ZnO}$ on antibacterial activity — Effect of specific surface area. J. Ceram. Soc. Jpn. 1998, 106, 1007-1011.

[4] Sanson, M.; Thillet, J.; Hoang-Xuan, K. Molecular changes in gliomas. Curr. Opin. Oncol. 2004, 16, 607-613.

[5] Ahmed Rasheed, B. K.; Wiltshire, R. N.; Bigner, S. H.; Bigner, D. D. Molecular pathogenesis of malignant gliomas. Curr. Opin. Oncol. 1999, 11, 162-167.

[6] Prados, M. D.; Levin, V. Biology and treatment of malignant glioma. Semin. Oncol. 2000, 27, 1-10.

[7] Suslick, K. S.; Hammerton, D. A.; Cline, R. E. The sonochemical hot spot. J. Am. Chem. Soc. 1986, 108, 5641-5642.

[8] Suslick, K. S. The chemical effects of ultrasound. Sci. Am. 1989, 260, 80-86.

[9] Wang, H.; Joseph, J. A. Quantifying cellular oxidative stress by dichlorofluorescein assay using microplate reader. Free Radic. Biol. Med. 1999, 27, 612-616.

[10] Winterbourn, C. C.; Sutton, H. C. Hydroxyl radical production from hydrogen peroxide and enzymatically generated paraquat radicals: Catalytic requirements and oxygen dependence. Arch Biochem. Biophys. 1984, 235 116-126.

[11] Boudreau, R. T. M.; Conrad, D. M.; Hoskin, D. W. Differential involvement of reactive oxygen species in apoptosis caused by the inhibition of protein phosphatase 2A in Jurkat and CCRF-CEM human T-leukemia cells. Exp. Mol. Pathol. 2007, 83, 347-356.

[12]Decaudin, D.; Marzo, I.; Brenner, C.; Kroemer, G. Mitochondria in chemotherapy-induced apoptosis: A prospective novel target of cancer therapy. Int. J. Oncol. 1998, 12, 141-152.

[13] Xia, T.; Kovochich, M.; Brant, J.; Hotze, M.; Sempf, J.; Oberley, T.; Sioutas, C.; Yeh, J. I.; Wiesner, M. R. Nel. A. E. Comparison of the abilities of ambient and 
manufactured nanoparticles to induce cellular toxicity according to an oxidative stress paradigm. Nano Lett. 2006, 6, 1794-1807.

[14] Sawai, J.; Igarashi, H.; Hashimoto, A.; Kokugan, T.; Shimizu, M. Evaluation of growth inhibitory effect of ceramic powder slurry on bacteria by conductance method. J. Chem. Eng. Jpn. 1995, 28, 288-293.

[15]Bhattacharyya, S.; Gedanken, A. A template-free, sonochemical route to porous $\mathrm{ZnO}$ nano-disks. Micropor. Mesopor. Mater. 2008, 110, 553-559.

[16] Soule, H. D.; Maloney, T. M.; Wolman, S. R.; Peterson, Jr., W. D.; Brenz, Jr., R.; McGrath, C. M.; Russo, J.; Pauley, R. J.; Jones, R. F.; Brooks, S. C. Isolation and characterization of a spontaneously immortalized human breast epithelial cell line, MCF-10. Cancer Res. 1990, 50, 6075-6086.

[17] Kumar, B.; Koul, S.; Khandrika, L.; Meacham, R. B.; Koul, H. K. Oxidative stress is inherent in prostate cancer cells and is required for aggressive phenotype. Cancer Res. 2008, 68, 1777-1785.

[18] Blass, M.; Kronfeld, I.; Kazimirsky, G.; Blumberg, P. M.; Brodie, $C$. Tyrosine phosphorylation of protein kinase $C \delta$ is essential for its apoptotic effect in response to etopo side. Mol. Cell Biol. 2002, 22, 182-195.

[19] Okhrimenko, H.; Lu, W.; Xiang, C. L.; Ju, D. H.; Blumberg, P. M.; Gomel, R.; Kazimirsky, G.; Brodie, C. Roles of tyrosine phosphorylation and cleavage of protein kinase $C \delta$ in its protective effect against tumor necrosis factorrelated apoptosis inducing ligand-induced apoptosis. J. Biol. Chem. 2005, 280, 23643-23652.

[20]Wacker, W. E. C.; Ulmer, D. D.; Vallee, B. L. Metalloenzymes and myocardial infarction. New Engl. J. Med. 1956, 255, 450-456.

[21] Lin, W. S.; Huang, Y. W.; Zhou, X. D.; Ma, Y. F. In vitro toxicity of silica nanoparticles in human lung cancer cells. Toxicol. Appl. Pharmacol. 2006, 217, 252-259. 